\title{
Piptospatha teijsmannii (Araceae: Schismatoglottideae), a new species from Kepulauan Riau, Indonesia
}

\author{
Peter C. Boyce ${ }^{\mathrm{a} *}$ and Sin Yeng Wong ${ }^{\mathrm{b}}$ \\ ${ }^{a}$ School of Biological Sciences, Universiti Sains Malaysia, Pulau Pinang, Malaysia; ${ }^{b}$ Department of Plant Science \& Envionmental \\ Ecology, Faculty of Resource Science \& Technology, Universiti Malaysia Sarawak, Sarawak, Malaysia
}

(Received 19 August 2013; final version received 28 September 2013)

\begin{abstract}
A collection made in 1872 by Johannes Elias Teijsmann (J.E. Teijsmann 16705) on Pulau Lingga (Kepulauan Riau Province, Lingga Regency, Indonesia) has long been Piptospatha. Recent living collections have now shown that this collection is a taxonomic novelty, endemic to the Lingga Archipelago, and here described as Piptospatha teijsmannii. Piptospatha teijsmannii is morphologically most similar to Piptospatha ridleyi N.E.Br ex Hook.f., a species restricted to the Peninsular Malaysian states of Johor and Pahang, differing by the morphology of its flowers. Both P. teijsmannii and $P$. ridleyi are illustrated in colour, and differentiated with an identification key to the species of Piptospatha in Peninsular Malaysia and Lingga Regency. Speculation as to the possible evolutionary origin of $P$. teijsmannii is proffered.
\end{abstract}

Keywords: Araceae; Schismatoglottideae; Piptospatha teijsmannii; Piptospatha ridleyi; endemic; Kepulauan Lingga; Indonesia

\section{Introduction}

In resurrecting Piptospatha marginata (Engl.) N.E.Br., Wong et al. (2011) drew attention to a Teijsmann collection from Pulau Lingga [Kepulauan Riau Province, Lingga Regency, Indonesia-J.E. Teijsmann 16,705 (BO!)], which has been placed in Piptospatha marginata (Engler 1912) but, as noted by Alderwerelt (1922), did not convincingly match that species, despite the similarly pubescent staminate flowers. This same collection was assigned to Piptospatha ridleyi N.E.Br. ex Hook.f. by Bogner and Hay (2000) to which Wong et al. (2011) expressed doubts. Shortly after publication of the $P$. marginata paper, we acquired living plants from Pulau Singkep that seemed a convincing match for the Teijsmann collection, and then somewhat later plants of apparently the same species were acquired from Pulau Lingga. At length these collections flowered with us, and revealed that although indeed resembling $P$. ridleyi in their pubescent staminate flowers, and in producing a powerful fruity floral fragrance at anthesis, they were also highly distinct in the morphology of the flowers, and the proportions of the spadix zones. In light of these morphological distinctions, coupled with the geographical isolation of these Lingga populations from all known populations of $P$. ridleyi, we are describing the Lingga plants as a taxonomically novel species, Piptospatha teijsmannii P.C. Boyce \& S.Y. Wong, which we consider endemic to the Lingga Islands.
Piptospatha teijsmannii P.C. Boyce \& S.Y. Wong, sp. nov.

Diagnosis

Piptospatha teijsmannii is morphologically most similar to $P$. ridleyi, and together these two species are unique in the genus in producing a powerful fruity floral odour during anthesis. Piptospatha teijsmannii differs from $P$. ridleyi by the uniformly pale green spathe exterior (versus lower part green and spathe limb pale pink), the sessile (or only very briefly stipitate) spadix with the staminate flower zone three times longer than (versus equalling) the pistillate flower zone, a truncate (versus triangular-elevated) anther connective, anthers with terminal (not laterally displaced) pores, weakly isodiametric pale orange, papillate stigmas (versus isodiametric, green, glossy stigmas), and by the white, elongate-fusiform (versus yellow, somewhat squat obpyramidal) subpistillar staminodes.

Type: Indonesia, Kepulauan Riau Province, Lingga Regency, Pulau Lingga, Sungai Banda, 1872, J.E. Teijsmann 16,705 (holo BO!). Figures 1, 3A, 4.

\section{Description}

Rheophytic herb 15-35 cm tall. Roots strong, extensive, 1-2 mm diameter. Stem condensed, 1-5 cm long, 5$12 \mathrm{~mm}$ diameter. Leaves several together; petiole (3-)5$15(-20) \mathrm{cm}$ long, 0.9-2.5 mm diameter, reddish, adaxially canaliculate, sheathing only at the extreme base, the 

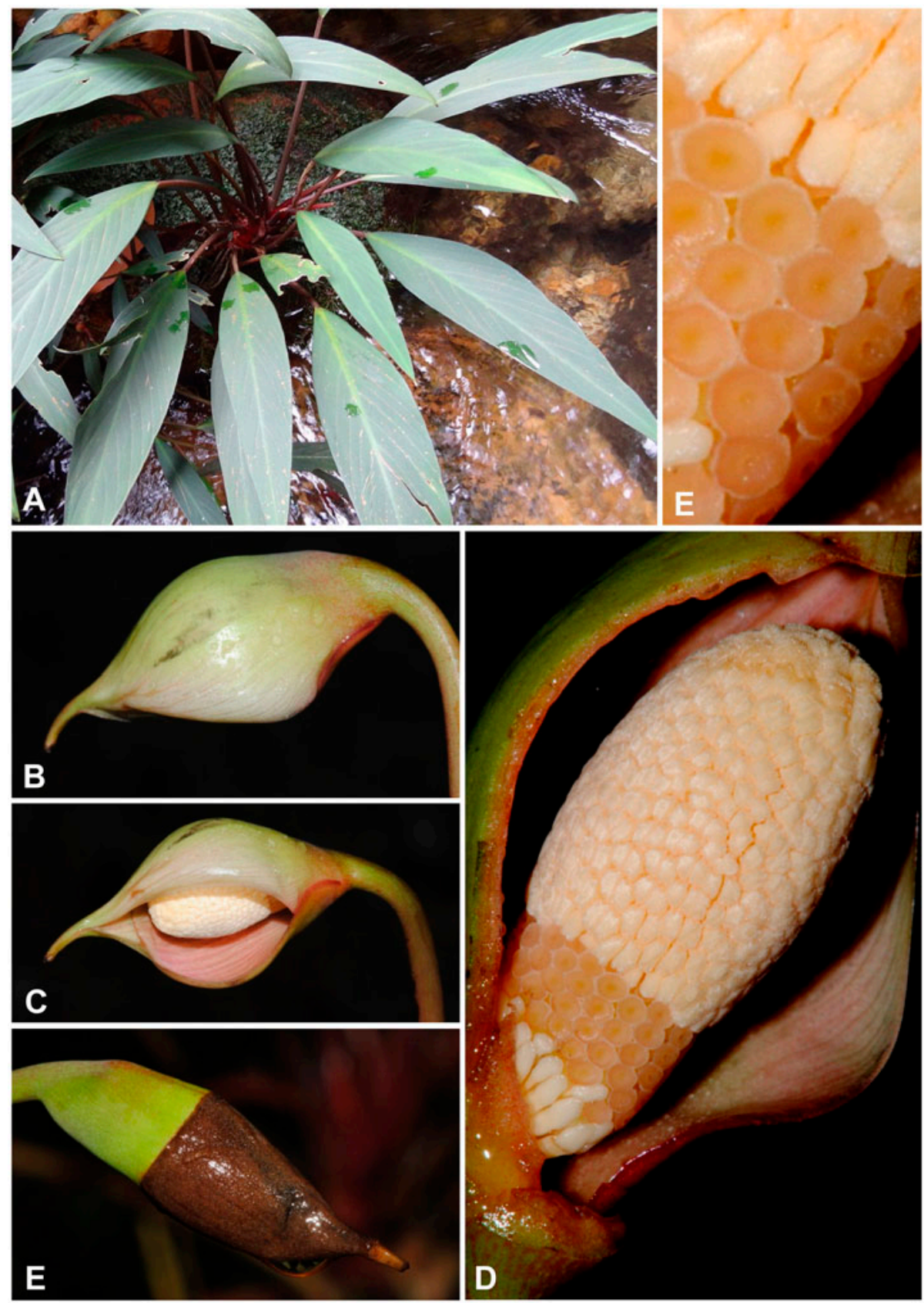

Figure 1. (A-E) Piptospatha teijsmannii P.C. Boyce \& S.Y. Wong. (A) Plants in habitat on Pulau Lingga. (B, C) Inflorescence at pistillate anthesis in lateral and three-quarter view. Note uniform exterior colour, and the pale pink interior. (D) Spadix (nearside spathe artificially removed) at pistillate anthesis. Note the colour and shape of the subpistillar staminode and stigmas. Note, too, the truncate stamens connective. (E) Post anthesis inflorescence with the spathe limb marcescent. All from K. Nakamoto AR-4021. Photo credits: (C) Peter C. Boyce.

wings extended into a narrow ligular portion $2-7 \mathrm{~cm}$ long at first reddish then drying brown; blade narrowly elliptic (4-)6-18(-25) $\mathrm{cm}$ long by (1-)2.5-6 cm wide, thinly coriaceous, base cuneate, apex acute and apiculate for 1-3 mm, adaxially dark green, abaxially paler with all primary and interprimary veins distinctly reddish; midrib abaxially prominent, adaxially slightly impressed, with $5-7(-12)$ primary lateral veins on each side, these diverging at c. $30-60^{\circ}$, running to a distinct submarginal vein; interprimary lateral veins less prominent than the primaries. Inflorescence several produced sequentially, each separated by a conspicuous prophyll or somewhat reduced foliage leaf, powerfully fruity fragrant at anthesis; peduncle exceeding the petioles at anthesis, terete, $10-25 \mathrm{~cm}$ long, reddish brown. Spathe initially narrowly ovoid, expanding during anthesis to broadly ovoid, c.3.5-4.7 cm long, exterior pale green with weak pinkish suffusion, veining, and speckling in the caducous upper part, interior deep pinkish red with several deeper pink ridges running from the mid-point to the terminal opening, spathe apically abruptly beaked for c. $9 \mathrm{~mm}$, at anthesis spathe limb inflating and gaping ventrally. 

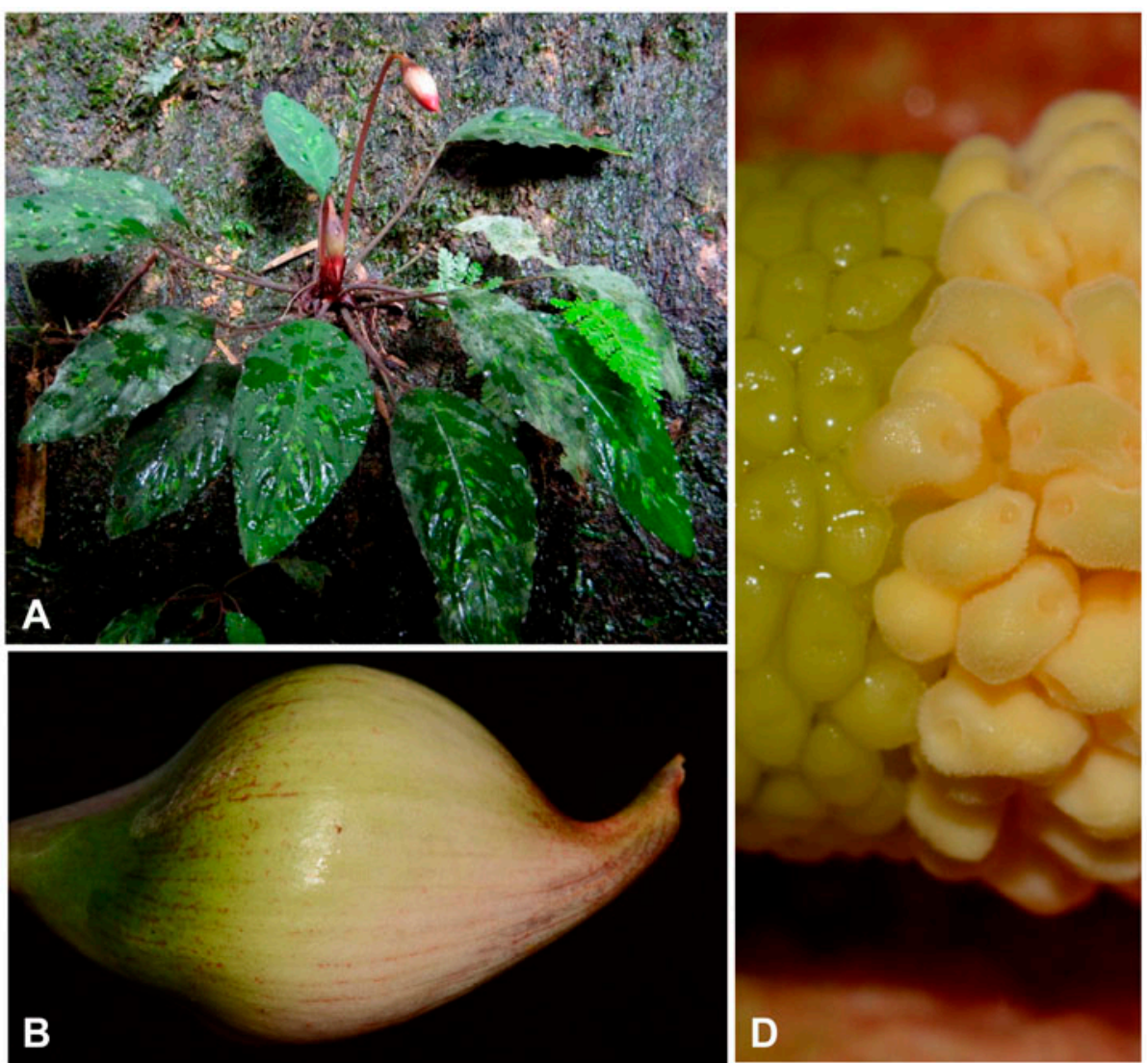

B
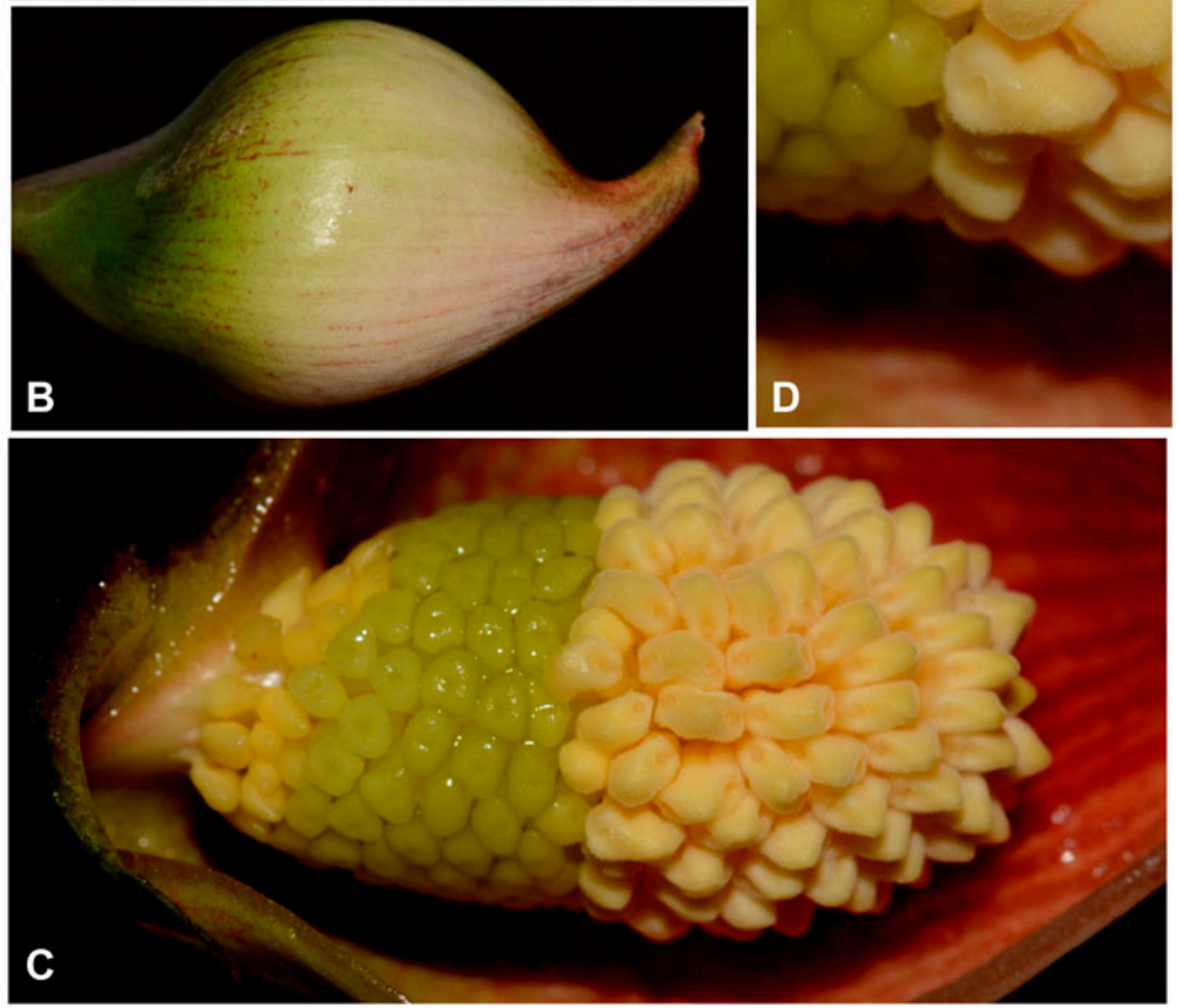

Figure 2. (A-D) Piptospatha ridleyi N.E.Br. ex Hook.f. (A) Plant in habitat at Endau Rompin N.P., Peninsular Malaysia. (B) Inflorescence at pistillate anthesis. Note the contrast in colour between the lower spathe and the spathe limb. (C) Spadix (nearside spathe artificially removed) at pistillate anthesis. Note the conspicuous stipe, the colour and shape of the stigmas, and the elongated stamen connectives. (D) Detail of the junction of the pistillate and staminate flower zones. Note the displaced anther pores. All from K. Nakamoto AR-4021. Photo credits: (C) Peter C. Boyce.

Spadix sessile or very briefly stipitate, $2.3-2.6 \mathrm{~cm}$ long, subcylindric-clavate, about two-thirds the length of the spathe; pistillate flower zone c. $4.5 \mathrm{~mm}$ long $\times 7 \mathrm{~mm}$ diameter; pistils more or less ovoid, c. $0.5 \mathrm{~mm}$ diameter; stigma very slightly raised on an indistinct style, discoid to weakly isodiametric, wider than the ovary, at anthesis densely papillose with a deep central pit, pale orange; staminodes restricted to an irregular whorl at the base of the pistillate zone, and white, elongate-fusiform, roughly equalling the pistils; sterile interstice absent; staminate flower zone clavate-ellipsoid, somewhat broader than the pistillate zone, especially about mid-way, c. $17 \mathrm{~mm}$ long $\times 10 \mathrm{~mm}$ diameter, fertile to apex; stamens finely and densely pubescent, more or less rectangular, mostly aligned in pairs, congested, very pale orange, pores terminal separated by the truncate connective; pollen released in dense strings. Fruiting spathe initially with the spathe limb marcescent, but this soon falling, lower persistent part of spathe broadly obconic, c. $1.5 \mathrm{~cm}$ diameter, pale green. Fruit and seed not observed. 

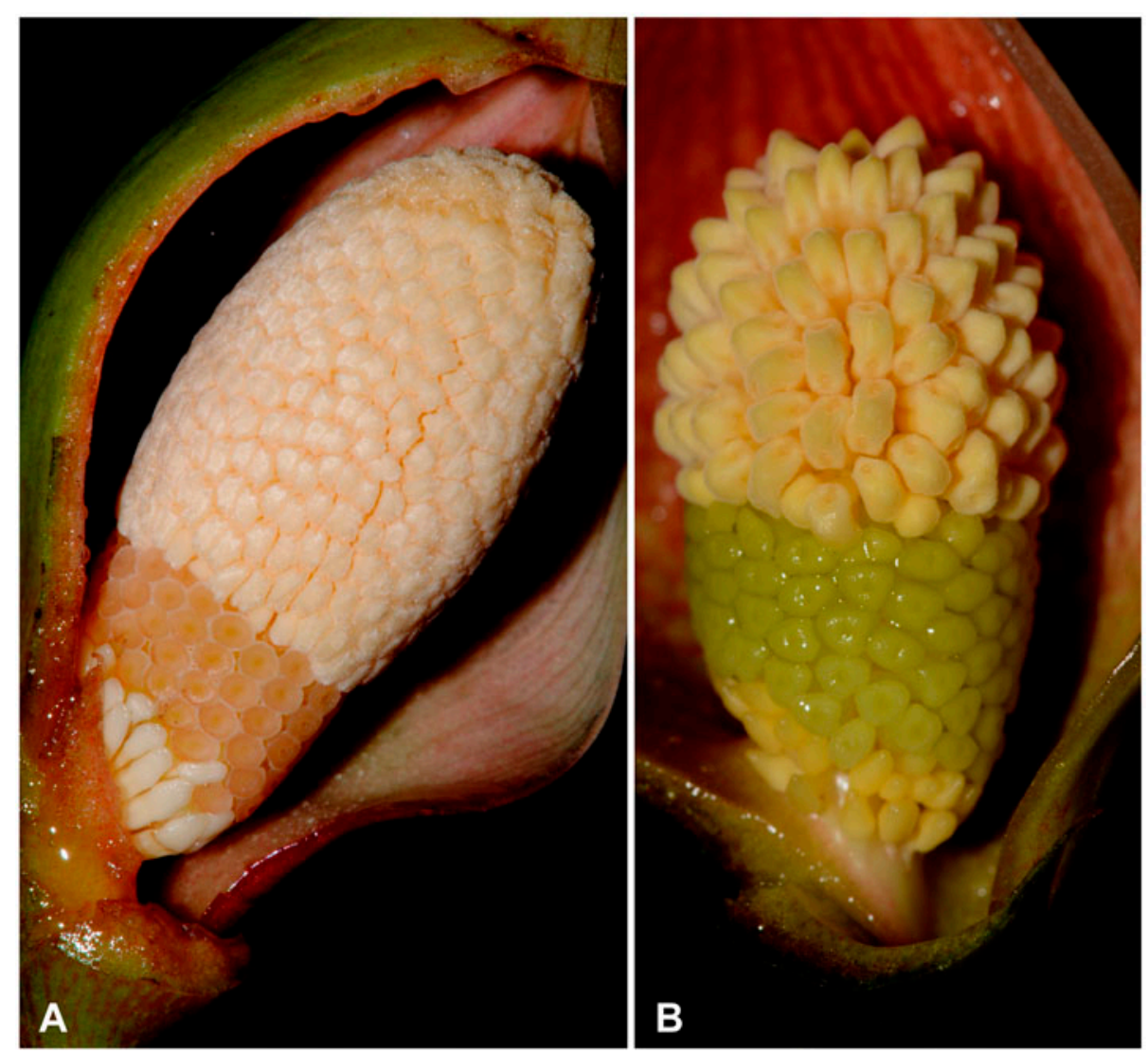

Figure 3. (A) Piptospatha teijsmannii P.C. Boyce \& S.Y. Wong. (B) Piptospatha ridleyi N.E.Br. ex Hook.f. Inflorescences at pistillate anthesis, nearside spathe artificially removed, to enable comparison of the spadices. (A) from K. Nakamoto AR-4021. (B) from P.C. Boyce et al. AR-3046. Photo credits (C) Peter C. Boyce.

\section{Distribution}

Kepulauan Riau Province, Lingga Regency, Indonesia. Known from three localities, two on Pulau Lingga and one on Pulau Singkep. At all three sites plants of P. teijsmannii are fairly abundant.

\section{Ecology}

Piptospatha teijsmannii is an obligate rheophyte on exposed or slightly shaded granite waterfalls in lowland to upper hill perhumid forest between 100 and $800 \mathrm{~m}$ above sea level.

\section{Eponymy}

Named for Johannes Elias Teijsmann (1808-1882), from 1831 to 1869 Curator of the Buitenzorg Botanic Gardens (Kebun Raya, Bogor). During his long term of office Teijsmann undertook extensive botanical explorations throughout the then Dutch East Indies (modern Indonesia). In later years he did much valuable work stemming from his interest in crop plants.

Notes

Piptospatha teijsmannii and $P$. ridleyi are evidently very similar. Externally, apart from the colour of the spathe, the inflorescences of both species are almost identical (com- pare Figure 1B with Figure 2B). Comparison of the spadices, however, reveals marked and consistent differences (compare Figure 1D, E with Figure 2C, D and see also Figure 3). Although yet to be investigated with molecular techniques, it seems highly probable that $P$. teijsmannii and $P$. ridleyi are closely related, with the geographical and ecological proximity raising the distinct possibility that they are vicariant taxa evolved from a common ancestral population fragmented by rising sea levels on the Sunda Shelf during the Pleistocene (Voris 2000).

Piptospatha now stands at 15 species, with 12 endemic to Borneo. It is an interesting observation that the only three species (Piptospatha perakensis (Engl.) Engl., $P$. ridleyi and $P$. teijsmannii) with a perceptible floral fragrance are extra-Bornean. In general, Bornean Piptospatha species have brightly coloured spathe limbs, ranging from bright pink to rich magenta (Boyce and Wong 2013a,b,c; Wong and Boyce, 2012a,b, 2013; Wong et al. 2009, 2011). Although detailed observations are wanting it seems highly probable that the Bornean species employ a different pollination strategy to the species with sombre hued but powerfully fragrant inflorescences.

\section{Other material examined}

Indonesia. Kepulauan Riau Province. Lingga Regency, Pulau Singkep, Riam Batu Ampar, 00²5'41.1" S, 


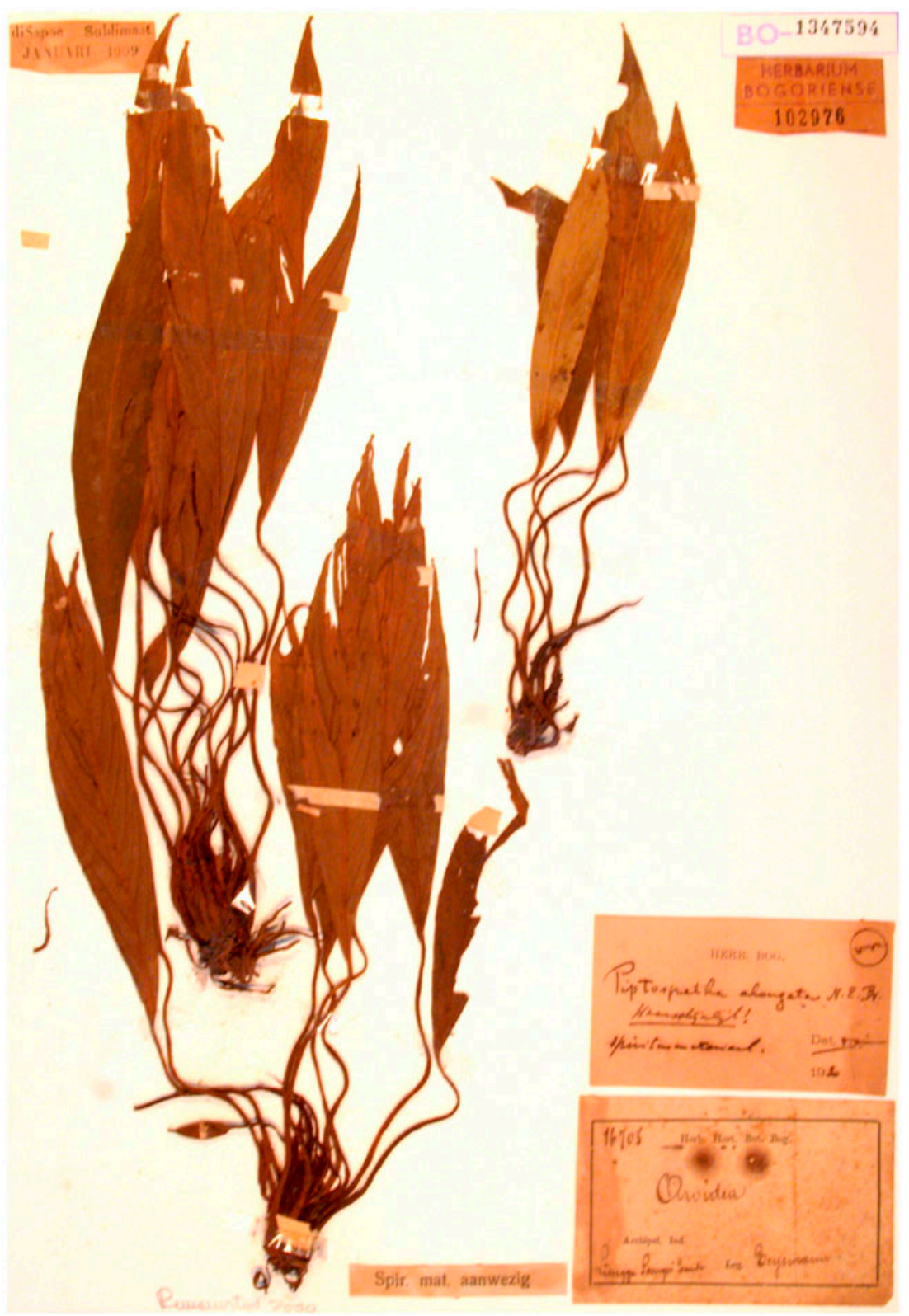

Figure 4. Piptospatha teijsmannii P.C. Boyce \& S.Y. Wong. Holotype J.E.Teijsmann 16705 (BO). Photo credits (C) Peter C.Boyce.

104'31'53.4" E, 5 November 2010, K. Nakamoto $A R-3121$ (BO!). Pulau Lingga, northeast of Daik Kampong, Riam Resun, $0^{\circ} 12^{\prime} 0.00^{\prime \prime} \mathrm{S}, 104^{\circ} 33^{\prime} 00.00^{\prime \prime} \mathrm{E}$, 7 November 2010, K. Nakamoto AR-3119 (BO!) and 25 August 2012, K. Nakamoto AR-4022 (BO!) and 23 January 2013, K. Nakamoto AR-4121 (BO!) and 17 May 2013, K. Nakamoto AR-4153 (BO!).

\section{Key to the species of Piptospatha in Peninsular} Malaysia and Kepualuan Riau

1a. Spathe limb white on both surfaces; inflorescence smelling of jasmine (benzyl acetate, linalool) at anthesis; leaf blades entirely green, abaxially with conspicuously tessellate venation. Widespread in Peninsular
Malaysia and extending to southwestern Thailand Piptospatha perakensis

1b. Spathe limb exterior greenish speckled and suffused pale red, to pale pink, interior pale pink; inflorescence smelling powerfully fruity (methyl benzoate?) at anthesis; leaf blades with the petiole and at least the primary veins reddish, abaxially lacking tessellate venation

.2

2a. Spadix sessile or only very briefly stipitate; staminate flower zone three times longer than the pistillate flower zone; connective of stamen slightly domed; anthers with terminal pores; stigmas discoid to weakly isodiametric pale orange, papillate; subpistillar 
staminodes white, elongate-fusiform. Pulau Lingga and Pulau Singkep

Piptospatha teijsmannii

2b. Spadix stipitate, with stipe adnate to lower spathe; staminate flower zone equalling the pistillate flower zone; connective of stamen triangular-elevated; anthers with laterally displaced pores; stigmas isodiametric, green, glossy; subpistillar staminodes fusiform yellow, somewhat squat-fusiform. Peninsular Malaysia (Johor and Pahang) Piptospatha ridleyi

\section{References}

Alderwerelt van Rosenburgh CRWK. 1922. New or noteworthy Malayan Araceae II. Bull Jard Bot Buitenzorg. 3(4):163-229.

Bogner J, Hay A. 2000. Schismatoglottideae in Malesia II Aridarum, Bucephalandra Phymatarum and Piptospatha. Telopea. 9(1):183-194.

Boyce PC, Wong SY. 2013a. Studies on Schismatoglottideae (Araceae) of Borneo XXXI - Piptospatha insignis re-found. Newslett Int Aroid Soc. 35(2):6-8.

Boyce PC, Wong SY. 2013b. Studies on Schismatoglottideae (Araceae) of Borneo XXIII: Piptospatha colata and P. deceptrix, taxonomic novelties from Borneo. Gard Bull Singapore. 65(1):7-17.
Boyce PC, Wong SY. 2013c. Studies on Schismatoglottideae (Araceae) of Borneo XXIX - Piptospatha manduensis - the ultimate aroid calciphile? Aroideana. 36:98-103.

Engler A. 1912. Araceae-Philodendroideae-Philodendreae-Homalomeninae und Schismatoglottidinae. In: Engler A, editor, Das Pflanzenreich 55(IV. 23Da): 1-134.W. Engelmann, Leipzig.

Voris HK. 2000. Maps of Pleistocene Sea Levels in South East Asia: Shorelines, River Systems. Time Durations. J Biogeogr. 27:1153-1167.

Wong SY, Boyce PC. 2012a. Schismatoglottideae of Borneo XIX - Piptospatha pileata, a remarkable new species from Kalimantan Timur, Indonesian Borneo. Willdenowia. 42:247-253.

Wong SY, Boyce PC. 2012b. The Araceae of Indomalaya II: Piptospatha N.E.Br. Malayan Nat J. 64(1): 9-32.

Wong SY, Boyce PC. 2013. Studies on Schismatoglottideae (Araceae) of Borneo XXV - A diminutive new Piptospatha from Sabah. Webbia. 68(1):3-5.

Wong SY, Boyce PC, Bogner J. 2009. Studies on Schismatoglottideae (Araceae) of Borneo VIII: A review of the Piptospatha elongata Group in West Sarawak. Gard Bull Singapore. 61(1):221-238.

Wong SY, Bogner J, Boyce PC. 2011. Studies on Schismatoglottideae (Araceae) of Borneo XIV: Piptospatha marginata resurrected and observations on Piptospatha, notably for the Rejang drainages. Webbia. 66 (1):29-32. 